\title{
Personality as a Predictor of Job Satisfaction: Study of the Relationship between Personality and Job
} Satisfaction amongst Workers in the Bahamas

\author{
Lavanda Cleare \\ Supervised by Mr. R. Oriakhi \\ College of The Bahamas
}

Received: June 28, 2013

Accepted: July 14, 2013

Published: July 14, 2013

doi:10.5296/jmr.v5i3.3936

URL: http://dx.doi.org/10.5296/jmr.v5i3.3936

\begin{abstract}
Job satisfaction is the most widely researched topic in organizational psychology. Over the years, evidence that job satisfaction is not primarily caused by factors originating within organizations has accumulated. More recently, researchers have begun exploring the role of extra-organizational factors, chiefly personality, in job satisfaction. It is suggested that personality is a dispositional source of job satisfaction, as some individuals are predisposed to negative affectivity, whilst others are predisposed to positive affectivity. In the present paper, the relationship between personality and job satisfaction amongst workers in The Bahamas was studied in a representative sample of 384 workers on New Providence. Theoretical implications of this research and suggestions for future work are discussed.
\end{abstract}

Keywords: Personality, Core Self-Evaluation, Job Satisfaction, The Bahamas, Caribbean 
For decades researchers have sought to explain and predict job satisfaction, largely because of its association with other key factors of organizational behavior (productivity, absenteeism, turnover, deviant workplace behavior, and organizational citizenship behavior), as well as its predication of employee subjective wellbeing, behavior and turnover intentions (Jonge, Bosma, Peter, \& Siegrist, 2000; Robbins \& Judge, 2007). Based on the prevailing management maxims that 'happy worker are satisfied workers' and 'satisfied workers are more productive workers', some organizations go to great lengths to map job satisfaction. They invest in job redesign, incentive and recognition programs, competitive pay strategies, benefit packages and perquisites, and career planning, all in an effort to reduce boredom and increase motivation and happiness. Research shows (Argyle, 1989) that happiness is highly correlated with job satisfaction, but whether or not jobs and/ or the organizations are sources of employees' happiness remains unknown.

\section{Statement of Problem}

Job satisfaction research suggests that organizations with the most satisfied workers are more successful, as dissatisfied workers are less productive, committed, supportive and cooperative in the workplace, and are more inclined to engage in negative organizational behaviors (such as voluntary absenteeism, sabotage, espionage, wastage, theft and violence) (Ostroff, 1992; Robbins \& Judge, 2007). Unfortunately for organizations in The Bahamas, over the last decade there have been a great number of strikes, protests, slowdowns, and industrial disputes, which indicate that workers are dissatisfied with their jobs (Missick, 2004; Saunders, 2005; Bahamas Press, 2008; Bahamas Local, 2011; Bahama Journal, 2012). Studies suggest that, personality may account for much of the variations in satisfaction amongst employees, as some personality traits have been found to be strongly associated with satisfaction, whilst others are strongly associated with dissatisfaction (Furnhama, Petridesa, Jackson, \& Cotter, 2002; Judge, Heller, \& Mount, 2002).

\section{Purpose of the Study}

The purpose of this study is to describe the relationship between personality and job satisfaction amongst workers in The Bahamas. The primary goal of the study is to determine the strength and direction of the relationship between personality traits and job satisfaction. The secondary goal is to determine if personality is a significant predictor of job satisfaction.

\section{Research Significance}

This descriptive study may be significant in providing managers a clearer understanding of the attitudes they may encounter in the workplace. Further, it can be a valuable aid to strategic human resource management efforts with respect to selection, job satisfaction, and retention.

\section{Limitations and Delimitations}

The greatest challenge I faced in conducting this research was the absence of literature specific to The Bahamas. The country has long accepted the conclusions of studies using populations with perceived social similarities, despite obvious cultural differences. However, 
as environment is one of the foremost determinants of personality, there is need for research addressing this topic in the Bahamian context. The present study is delimited to the relationship between personality and job satisfaction amongst workers in The Bahamas. It is neither concerned with the development of personality nor the determinants of personality. Personality traits are delimited to core self-evaluation traits (self-esteem, generalized self-efficacy, emotional stability and internal locus of control). Participants will be delimited to workers on New Providence due to time and financial constraints.

\section{Review of Literature}

The idea that personality can be a predictor of job satisfaction is relatively new and not widely accepted. There are a just handful of studies that have examined the relationship between job satisfaction and personality. However, the consistency amongst reported results suggests that personality may be a dispositional source of job satisfaction. The present study examines the relationship between personality and job satisfaction amongst workers in The Bahamas. This literature review looks at past research on the topic. First, it discusses the definition, concept and importance of job satisfaction, followed by determinants of personality, and finally personality traits and their relation to job satisfaction.

\section{Definition, Concept, and Significance of Job Satisfaction}

The earliest definition of job satisfaction was provided by philosopher Robert Hoppock in 1935. Hoppock defined job satisfaction as a combination of biological, emotional, and environmental circumstances that caused a person to say "I am satisfied with my job" (as cited in Sen, 2008, p. 1). One of the most commonly cited definitions, however, was provided by Locke (1969), who defined it as "the pleasurable emotional state resulting from the appraisal of one's job as achieving or facilitating the achievement of one's job values” (p. 317). This is somewhat similar to the definition found in most management textbooks: the positive feeling about one's job resulting from the evaluation of one's job experience or job characteristics (Mathis \& Jackson, 2008; Robbins \& Judge, 2007). The two latter definitions are essentially equivalent. They imply that job satisfaction is a positive feeling that results from the evaluation of extrinsic job factors. However, Hoppock's definition seems more fitting for the present study, given he acknowledged the role of genetic and environmental factors, the foremost determinants of personality, in the job satisfaction equation.

Locke (1969) is nonetheless valuable in explaining the concept of job satisfaction. According to his discrepancy theory, the concept of job satisfaction arises when there are discrepancies between what employees have and want. The theory holds that job satisfaction resulted from the attainment of something perceived as important or valuable, specifically the fulfillment of wants rather than needs, as people often have stronger desires for the things they want. The level of satisfaction attained, however, is dependent on two factors: (1) the importance of the need or want and (2) the difference between what is expected and what is received.

According to Robbins and Judge (2007) job satisfaction is a major job attitude - an evaluative statement concerning objects, people, and events. Attitude consists of three components: affective - emotional or feeling segment of attitude; cognitive - the opinion of 
belief segment of attitude and; behavioral - intention to behave in a certain way toward someone or something. Job satisfaction is a strong indicator of the degree to which employees identify with their jobs (job involvement), organizations and theirs goals (organizational commitment), believe that organizations value their contributions and care about their wellbeing (perceived organizational support), and are satisfied with and enthusiastic about work (employee engagement). However, it seems understanding the consequences of job dissatisfaction communicates the significance of the concept more effectively. When employees dislike their jobs they do one of two things: (1) they quit, taking with them the wealth of knowledge and experience they may have attained at organizations' expense, or (2) they stay and (a) voice their displeasure to their supervisors or take union action; (b) allow conditions to worsen, neglect work responsibilities, reduce effort, and are chronically and voluntarily absent or; (c) remain loyal and optimistic and patiently wait for conditions to improve. The latter is an ideal response to job dissatisfaction.

\section{Theories on Job Satisfaction}

\section{Hierarchy of Needs Theory}

Maslow (1943) hierarchy of needs theory postulated that, human needs can be classified in five basic categories. In the context of the organization these are: (from lowest) physiological needs - the need for wages or a salary that cover the cost of living and safe and healthy physical working conditions; safety needs - the need for job security and stability, and protection from harm; belongingness needs - the need to be befriended and accepted as a part of a group; esteem needs - the need for achievement, and respect and recognition from others; self-actualization needs - the need for meaningful and interesting work, opportunities for growth, and advancement. According to Maslow, job satisfaction can only be attained through the fulfillment of gratification or intrinsic needs (i.e. esteem needs and the need for self-actualization). Before individuals can activate such needs, they must singly and sequentially satisfy extrinsic needs, also termed deprivation or deficiency needs (i.e. physiological, safety, and belongingness needs). Thus, deprivation needs are merely hurdles that must be overcome before job satisfaction can become attainable.

However, other studies showed that it is possible for employees to attain job satisfaction without fulfilling lower level needs, and that higher level needs can be satisfied before lower level needs. Two separate studies on agricultural faculty found that employees were dissatisfied with pay in one instance, and physical working conditions in another, yet they were satisfied with the work itself. Moreover, despite the fact that these lower level needs were unfulfilled they were satisfied with their jobs overall (Bowen \& Radhakrishna, 1991; Castillo \& Cano, 2004). Recognizing the shortcomings of this theory, Maslow noted that there are numerous exceptions to the hierarchy of needs theory and stressed that human behavior is "multidetermined" and "multimotivated" (as cited in Wahba \& Bridwell, 1976, p. 214).

Two-Factor Theory

Herzberg, Mausner and Snyderman's (1959) two-factor theory was heavily influenced by the 
hierarchy of needs theory. This theory holds that, job satisfaction is caused by motivator factors (intrinsic factors) such as achievement, recognition, the work itself, responsibility, and advancement. Job dissatisfaction or no satisfaction, on the other hand, is caused by hygiene factors (extrinsic job factors) such as supervision, interpersonal relations, company policy and administration, physical working conditions, salary, benefits, and job security (as cited in Stello, 2011).

The two-factor theory has received significant criticism for its entrenched hedonic bias crediting oneself for successes and blaming others for failures (Behling, Labovitz, \& Kosmo, 1968) - and for confusing correlation with causation - it assumed that because hygiene factors were correlated with bad experiences, they also caused dissatisfaction or no satisfaction (Stello, 2011). Behling et al. (1968) also noticed that the theory is methodologically bounded, as other studies using Herzberg's et al. critical-incident approach have yielded supporting results, whilst those using other approaches have yielded conflicting results. This was proven to be true particularly in the case of interpersonal relations, salary, and the work itself (Argyle, 1989; Churchill, Ford, \& Walker, 1976; Ganzach, 1998).

Moreover, Herzberg et al. overlooked the grave possibility that individuals themselves may be the underlying source of dissatisfaction. Morris and Maisto (2008), for example, asserted that, depressed employees tend to evoke anxiety and hostility in others because they require more emotional support than people are comfortable with giving. This not only suggests that emotionally unstable employees are more likely to be dissatisfied with interpersonal relations, but also that they may be the source of their bad feelings and thus the source of their dissatisfaction. Another interesting example is provided Maume and Sebastian (2007) who found that, when required to work alongside a number of minority coworkers, achievement amongst white employees was correlated with job dissatisfaction. It is not rational to conclude that minority coworkers were the cause of declines in job satisfaction amongst white workers, but rather it was the personal feelings and beliefs of the individuals in question that generated the negative feelings.

\section{Job Characteristics Model}

The job characteristics model originated with Hackman and Oldman (1975), who argues that job design can create work conditions that negatively or positively affect job satisfaction. According to the theoretical model, job satisfaction can be improved by enhancing five characteristics of jobs: task identity - completing a clear and identifiable piece of work; task significance - the extent to which the job has an impact on the lives of others; skill variety - the extent to which the job requires a variety of skills and abilities; autonomy - the extent to which the job provides freedom, independence and discretion; and feedback - the extent to which information about effectiveness is available. Hackman and Oldman (1976) contended that enhancing these five features would lead to job enrichment - increased autonomy - and job enlargement - increased responsibility - which in turn positively impacts job attitude. Conversely, studies showed that job redesign does not necessarily increase job satisfaction. Argyle (1989) found that, increased responsibility only increased job satisfaction when accompanied by increased pay, and others times, increased responsibility did not increase job 
satisfaction despite complementary increases in pay. Additionally, Ganzach (1998) found that, job enlargement caused job dissatisfaction when it involved a variety of complex tasks.

The prevailing theories on job satisfaction are all based on the assumption that job satisfaction is dependent on intra-organizational factors - factors directly related to jobs and / or surrounding jobs. Clearly all three theories have their methodological limitation. Their fallibility is that they continue to fail to predict job satisfaction and do not account for variations in satisfaction amongst workers (perhaps this is because job satisfaction is anchored to the wrong variables). The history of research on the relationship between personality and job satisfaction, though relatively brief, is significant in explaining these variances. The following sections discuss personality, with special emphasis on the relationship between personality and job satisfaction.

\section{Determinants of Personality}

\section{Genetics}

Staw and Ross (1985) claimed that, job attitude may reflect a biologically based trait that predisposes individuals to see people, things, and situations in their lives as either negative or positive. They asserted that individuals' predispositions influence how they input, recall, and interpret various social situations in their lives. There are a number of studies that provide support for this theory. The Minnesota Study of Twin Reared Apart (MSTRA), which has followed twins for over ten years supported that genetics is a significant determinant of individuals' interests, talents, intelligence, and mental health (Morris \& Maisto, 2008; Tellegen, Bouchard Jr., Wilcox, Lykken, \& Rich, 1988). In a sample of 34 monozygotic twin pairs that had been separated at birth and reared apart, Abraham, Arvey, Bouchard, and Segal (1989) found, strong correlates for intrinsic satisfaction, extrinsic satisfaction and general satisfaction. In addition, siblings chose jobs that were similar in complexity, motor skills requirements, and physical demands. However, Abraham et al. acknowledged that, only 30\% of the variance for intrinsic and general satisfaction is due to genetic factors.

\section{Environment}

The impact of environment on personality development is articulated best by American psychologist John B. Watson who stated:

Give me a dozen healthy infants, well-formed, and my own specialized world to bring them up in, and I'll guarantee to take any one at random and train him to become any type of specialist I might select - doctor, lawyer, artist, merchant, chief and, yes, even beggar man, and thief, regardless of his talents, penchants, tendencies, abilities, vocations, and race (as cited in Tischler, 2007, p.15).

Watson insinuated that whilst people may be born with particular abilities, temperaments, and proclivities, their personalities are not impervious to life experiences. According to Erikson (1978) more than 50\% of personality development occurs during childhood. He claimed that, during first year of life individuals learn to be either trusting of themselves and others or 
suspicious and fearful, and by age 11, they have already established either a sense of independence and confidence or self-doubt and shame; a sense of joy in taking on new challenges or strong feelings of guilt, unworthiness, and resentment; and a sense of self-sufficiency or feelings of inadequacy and inferiority.

Other studies supported Erikson's theory. For example, in a secondary analysis Hart, Atkins, Fegley, Robins, and Tracy (2003) found that, childhood experiences play a significant role in personality development and shifts in personality amongst children. They identified three major personality types amongst children: (1) resilient - children that are verbal, self-confident, independence and have the ability to concentrate on task; (2) overcontrolled children that are shy, quiet, nervous, and dependable; (3) undercontrolled - children that are impulsive, stubborn, and physically active. They found that, at age six children with undercontrolled personalities were more depressed and anxious, dependent, withdrawn from peers and conflict oriented, antisocial, hyperactive, and headstrong than children with other personality types. At age 11 they had more behavior problems, and experienced significant declines in academic achievement, whilst achievement amongst other types remained relatively constant. They concluded that though personality traits are not stable from childhood to adulthood, patterns of behavior are connected.

Despite compelling arguments from both sides, researchers have failed to prove that personality is fully dependent on genetics or environment. In my view personality is an extricable combination of both genetic and environmental components. Recent studies support that, gene-environment interactions account for the unique differences amongst individuals (Horwitz, Videon, Schmitz, \& Davis, 2003; Markon, Krueger, Bouchard, \& Gottesman, 2002; Lykken, Bouchard, McGue, \& Tellegen, 1993).

\section{The Relationship between Personality and Job Satisfaction}

Judge et al. (2002) emphasized the tripartite affect of personality on job satisfaction. They asserted that, the cognitive component of personality influenced how individuals interpret characteristics of their jobs; the affective component influences individuals' mood at work; and the behavioral component operates through job performance. The present study examined this relationship using the core self-evaluation (CSE) theory of personality. CSE, which composes of four bi-polar personality traits (self-esteem, generalized self-efficacy, emotional stability, and locus of control) was introduced by Judge, Locke, and Durham (1997). The theory holds that individuals with positive CSE are likely to be satisfied with their jobs because they do not focus on negative factors or experiences. Conversely, individuals with negative CSE are more likely to be dissatisfied because they are highly sensitive to bad experiences and perceive the workplace more negatively (Brunborg, 2008). This section looks at core self-evaluation traits and their relation to job satisfaction separately.

\section{Self-Esteem}

Literature suggests that self-esteem - is the extent to which individuals like or dislike themselves and believe that they are worthy or unworthy as a person - affects job satisfaction (Robbins \& Judge, 2007). Sanna (2000) argues that self-esteem plays a significant role in 
how individuals perceive and respond to content in their lives. Individuals with high self-esteem are governed by self-enhancing motives. They are much like optimists because they expect positive outcomes, but also have the mental capacity to repair bad moods quickly when negative outcomes do occur. Individuals with low self-esteem, on the other hand, are governed by self-protective motives. They expect negative outcomes to occur and tend to psychologically prepare themselves for disappointment. Their disposition is based on their retrospection on negative experiences and as such they are prone to feeling negative emotions.

Even more, Locke, McClear, and Knight (1996) found that individuals with high self-esteem view challenging jobs as deserved opportunities to master and benefit from, whereas individuals with low self-esteem are more likely to view them as undeserved opportunities or chances to fail. Fleishman (1984) agreed that individuals with high self-esteem have confidence in their ability to overcome adversity. They maintain positive outlooks and tend to ignore or deny negative or threatening information. These studies suggest that self-esteem should be related to job satisfaction, as individuals with high self-esteem are optimistic about work outcomes, cope well with stressful situations, and are less sensitive to negative experiences. Based on the above discussion, the study presents the following hypothesis:

\section{H1a: Self-esteem is positively related overall job satisfaction.}

\section{H1b: Self-esteem is positively related to satisfaction with job facets.}

\section{Generalized Self-Efficacy}

Judge and Bono (2001) defined generalized self-efficacy as an "estimate of one's fundamental ability to cope, perform, and be successful” (p. 80). They argue that, individuals with high generalized self-efficacy deal more effectively with difficulties, persist in the face of failure, and are more likely to attain valued outcomes. Sanna (2000) argues that generalized self-efficacy leads individuals to either negatively or positively interpret reality. He found that people with high generalized self-efficacy interpret challenging tasks and the accomplishments of others positively because they perceive them to be achievable. Oppositely, individuals with low generalized self-efficacy interpret such content negatively because they doubt their ability to achieve success and thus perceive them as being unattainable. In a sample of 255 respondents, Judge and Hulin (1990) found that, individuals with the dispositional tendency to respond negatively to neutral objects in their environment have lower levels job satisfaction than those that have the dispositional tendency to respond positively to neutral objects. They explained that dispositions, which are reflections of overall happiness and life satisfaction, are transferred to the workplace and thus have a direct impact on job attitude. These studies suggest that, individuals with high generalized self-efficacy should be satisfied with their jobs, as they are motivated by the intrinsic and extrinsic rewards that high performance provides. Based on the foregoing discussion, the study presents the following hypothesis:

\section{H2a: Generalized self-efficacy is positively related to job satisfaction.}

H2b: Generalized self-efficacy is positively related to satisfaction with job facets. 
Emotional Stability

Judge and Larson (2001) defined low emotional stability as individulas' tendency to exhibit poor emotional adjustment and experience negative emotions. They suggested that employees with low emotional stability are likely to be dissatisfied with their jobs, as they tend to socially withdraw in response to dissatisfying job conditions, allowing situations to get worse. Oppositely, low-neuroticism employees respond by proactively attempting to identify and fix the source of the dissatisfaction. Additionally, Judge (2009) suggested that low emotional stability should be negatively related to job satisfaction because it is a strong predictor of job stress. In a meta-analysis of over 280 articles and dissertations, Judge et al. (2002) found that, emotional stability (low neuroticism) is more strongly correlated to job satisfaction than all of the other personality triats in the five-factor model. They explained that, individuals with high emotional stability are likely to be satisfied with their jobs because emotional stability is a key aspect of happy personalities. Employees with low emotional stability, on the other hand, are likely to be dissatisfied with their jobs because of their tendency to dwell on negative experiences in the workplace, and to feel nervous, worried, embarrassed, irritated, and depressed.

Furnhama et al. (2002) found similar results in a survey. In a sample of 92 job applicant they found that, neurotic individuals were inclined to empasize negative aspects of jobs. Nevertheless they concluded that, the influence of personality on job satisfaction "is, at best, modest," as the correlation is not significant enough to be highly consistent and replicable (pp. 1333, 1339). However, Furnham et al. results were strongly influenced by their sample and questionnaire design. Firstly, the sample itself (which composed of job applicants who were full-time employees in one of three different companies in positions ranging from administration to senior management) may have prejudiced the outcome of the study, as job applicants are likely to be ego-defensive and may therefore deliberately falsify answers. Secondly, the questionnaire design was prone to generate respondent error. The questionnaire asked respondents to indicate how much each job facet "would contribute to their "feeling happy at work'” (p. 1334). As participants held either administrative or managerial positions and were looking for new jobs, these questions were likely to cause social desirability bias ${ }^{1}$. Based on the above discussion, the study presents the following hypothesis:

\section{H3a: Emotional stability is positively related to job satisfaction.}

\section{H3b: Emotional stability is positively related to satisfaction with job facets.}

\section{Locus of Control}

Locus of control is the extent to which individuals believe that they are masters of their own fate (Robbins \& Judge, 2007). According to Judge (2001), individuals with internal locus of control believe that they control their lives, whilst those with external locus of control believe that their lives are controlled by external forces, such as, luck, chance, fate, or other people. Brunborg (2008) suggested that internal locus of control should be positively related to job

\footnotetext{
${ }^{1}$ According to Zikmund (2003) social desirability bias occurs when respondents are dishonest in survey responses because they wish to create favorable impressions of themselves.
} 
satisfaction due to its positive correlation with subjective well-being and negative correlation with job stress. Judge and Bono (2001) argue that individuals with internal locus of control are more likely to be satisfied with their jobs because they are less likely to stay in a dissatisfying job and are more likely to be successful in organizations. Based on the above discussion, the present study presents the following hypothesis:

\section{H4a: Internal locus of control is positively related to job satisfaction.}

\section{H4b: Internal locus of control is positively related to satisfaction with job facets.}

Personality is inextricably dependent on genetic and environmental factors. It is a unique composite of traits that determine the extent to which individuals are self-confident, believe in their ability to succeed, emotionally stable, and believe that they are in control of situations in their lives. Literature supports that personality may be a dispositional source of job satisfaction. It suggests that self-esteem, emotional stability, generalized self-efficacy, and internal locus of control are positively related to positive affectivity, and thus are likely to be positively related with job satisfaction, and as such satisfaction with job facets.

Further, research suggests that personality can account for the variations in job satisfaction amongst workers. Studies show that individuals are predisposed to feel negatively or positively about their jobs. This present study builds on existing studies by examining the relationship between personality and job satisfaction in an unexplored social and cultural context. Based on the previous discussions, the conceptual framework is proposed as depicted in Figure 1.

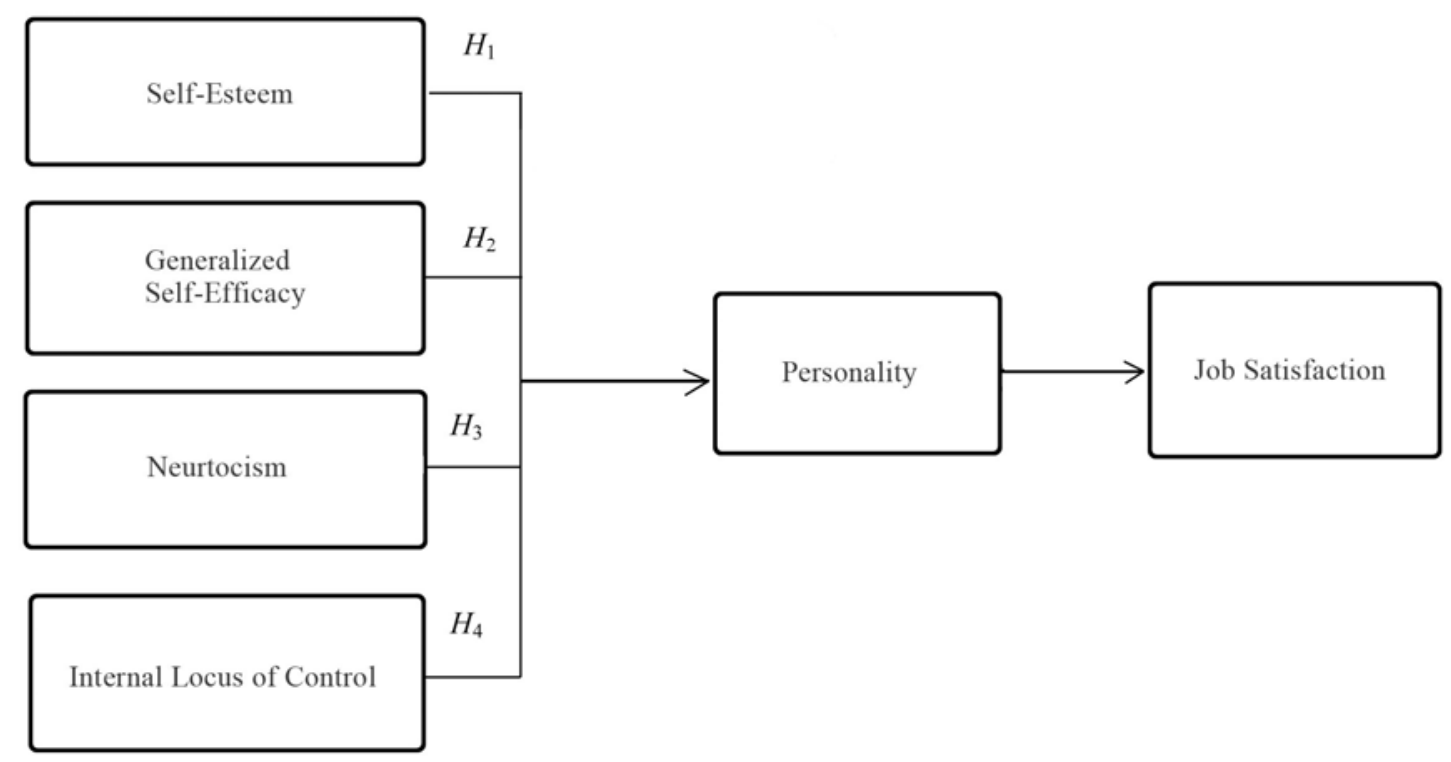

Figure 1. A proposed conceptual framework for the relationship between personality and job satisfaction 
Hypothesis:

H1a: Self-esteem is positively related overall job satisfaction.

H1b: Self-esteem is positively related to satisfaction with job facets.

H2a: Generalized self-efficacy is positively related to job satisfaction.

H2b: Generalized self-efficacy is positively related to satisfaction with job facets.

H3a: Emotional stability is positively related to job satisfaction.

H3b: Emotional stability is positively related to satisfaction with job facets.

H4a: Internal locus of control is positively related to job satisfaction.

H4b: Internal locus of control is positively related to satisfaction with job facets.

\section{Methodology}

The purpose of this descriptive study is to examine the relationship between personality and job satisfaction amongst workers in The Bahamas. The objectives are to determine 1) the strength and direction of the relationships and 2) if personality can be used to predict job satisfaction. Based on the findings of past studies, I hypothesized that self-esteem, generalized self-efficacy, emotional stability and internal locus of control were positively related to job satisfaction. Further, it was hypothesized that all four traits were positively related to 13 job facets. The research strategy of choice was quantitative, as it allowed for the development of testable hypotheses, measurement of the subject using objective methods, and provides statistical proof. Further, a quantitative approach is a stronger measure for descriptive aspects of behavior.

\section{Target Population}

The population of the study was all employed individuals in The Bahamas.

According to the Department of Statistics (2011) this population composed of 164,120 individuals: females $=81,850$; males $=82,270$.

\section{Sampling Method}

Probability sample was chosen for this study to ensure that results were generalizable to the population of workers in The Bahamas. The sampling procedure was simple random sampling.

\section{Sample Size}

Based on a population of 164,120 individuals, and using a 95\% confidence interval, 5\% margin of error, and 50\% response distribution, the appropriate random sample size for this study was 384 (females $=192$; males $=192$ ) $($ Raosoft, 2004). The samples comprised of individuals between the ages of 18 and 64. All participants worked on New Providence.

\section{Instrumentation and Measurement Tools}

The methodological approach used in the present study was survey design using self-administered questionnaire. My rationale for this methodology was the ability to (1) gather primary data quickly, efficiently and inexpensively, (2) use structured question that 


\section{Macrothink}

Journal of Management Research

ISSN 1941-899X

2013, Vol. 5, No. 3

limit the number of responses available, which makes it less difficult to edit and code raw data and conduct analysis, and (3) ensure that all data collected was relevant to the research problem.

\section{Variables}

The independent variables measured were the four core self-evaluation traits: self-esteem, generalized self-efficacy, emotional stability, and internal locus of control. Dependent variables included overall job, as well as 13 job factors as proposed by Herzberg et al. (1959): achievement, advancement, recognition, responsibility, the work itself, benefits, company policy and administration, relationship with coworkers, relationship with supervisor, job security, physical working conditions, salary, and supervision (as cited in Stello, 2011).

Questionnaire Design

According to Zikmund (2003) relevance and accuracy are the two basic criteria that must be met if the survey instrument is to measure what it is intended to measure. Relevancy requires that no unnecessary information is collected and that all information that is collected aids in answering the research question. Accuracy requires that the information gathered is reliable and valid. This process involves ensuring that questions are not lengthy, difficult to answer or ego-threatening, and are simple, unambiguously, and non-irritatingly worded. These factors were considered in developing the data requirement table (see table 1). 
Table 1. Data Requirement Table

Research Objective: Describe the relationship between personality and job satisfaction.

\begin{tabular}{|c|c|c|c|}
\hline Constructs & $\begin{array}{l}\text { Variables } \\
\text { Required }\end{array}$ & Detail in which data are measured & $\begin{array}{l}\text { Variable } \\
\text { type }\end{array}$ \\
\hline Locus of control & Behavioral & On a 5 point scale, rate in terms of agreement & Ordinal \\
\hline Self-Efficacy & Behavioral & On a 5 point scale, rate in terms of agreement & Ordinal \\
\hline Self-Esteem & Behavioral & On a 5 point scale, rate in terms of agreement & Ordinal \\
\hline Neuroticism & Behavioral & On a 5 point scale, rate in terms of agreement & Ordinal \\
\hline Achievement & Opinion & On a 5 point scale, rate in terms of satisfaction & Ordinal \\
\hline Advancement & Opinion & On a 5 point scale, rate in terms of satisfaction & Ordinal \\
\hline Benefits & Opinion & On a 5 point scale, rate in terms of satisfaction & Ordinal \\
\hline $\begin{array}{l}\text { Company Policy and } \\
\text { Administration }\end{array}$ & Opinion & On a 5 point scale, rate in terms of satisfaction & Ordinal \\
\hline Job Security & Opinion & On a 5 point scale, rate in terms of satisfaction & Ordinal \\
\hline $\begin{array}{l}\text { Physical Working } \\
\text { Conditions }\end{array}$ & Opinion & On a 5 point scale, rate in terms of satisfaction & Ordinal \\
\hline Overall Job & Opinion & On a 5 point scale, rate in terms of satisfaction & Ordinal \\
\hline Recognition & Opinion & On a 5 point scale, rate in terms of satisfaction & Ordinal \\
\hline $\begin{array}{l}\text { Relationship with } \\
\text { coworkers }\end{array}$ & Opinion & On a 5 point scale, rate in terms of satisfaction & Ordinal \\
\hline $\begin{array}{l}\text { Relationship with } \\
\text { supervisor }\end{array}$ & Opinion & On a 5 point scale, rate in terms of satisfaction & Ordinal \\
\hline Responsibility & Opinion & On a 5 point scale, rate in terms of satisfaction & Ordinal \\
\hline Salary & Opinion & On a 5 point scale, rate in terms of satisfaction & Ordinal \\
\hline Supervision & Opinion & On a 5 point scale, rate in terms of satisfaction & Ordinal \\
\hline The work itself & Opinion & On a 5 point scale, rate in terms of satisfaction & Ordinal \\
\hline Age & Attribute & Choose a single response from a list & Nominal \\
\hline Gender & Attribute & Choose a single response from a list & Nominal \\
\hline Education & Attribute & Choose a single response from a list & Nominal \\
\hline Income & Attribute & Choose a single response from a list & Nominal \\
\hline Industry & Attribute & Choose a single response from a list & Nominal \\
\hline Job status & Attribute & Choose a single response from a list & Nominal \\
\hline Years in current job & Attribute & Choose a single response from a list & Nominal \\
\hline \multicolumn{4}{|c|}{$\begin{array}{l}\text { Variable Key: Attribute: Respondent's characteristics. Opinion: How respondents feel about somethin } \\
\text { Behavioral: The way respondents tend to behave. }\end{array}$} \\
\hline
\end{tabular}

\section{Types of Questions and Structure}

All questionnaire items were closed-ended. This type of question was chosen because it limits the number of possible responses, making coding and data analysis processes less difficult. The personality assessment segment of the questionnaire was placed in the first section of the questionnaire. It consisted of 20 items. Responses were based on a 5 point likert scale 
(strongly disagree; disagree; uncertain; agree; strongly agree). Respondents were asked to circle the corresponding number to indicate how strongly they agreed or disagreed with a constructed statement. Disguised questions were used in this section to uncover traits that individuals may not be unaware of or unwilling to reveal. The job satisfaction assessment questionnaire, was the most complex segment, and thus was place in the middle of the questionnaire. It consisted of 14 items. Responses were based on a 5 point numerical scale ( 1 = extremely dissatisfied, 2 = dissatisfied, 3 = neutral, $4=$ satisfied, and $5=$ extremely satisfied). Respondents were asked to rate their satisfaction with their overall job and 13 job facets as proposed by Herzberg et al. (1959) (as cited in Stello, 2011). Finally, demographic characteristics section was placed at the end of the questionnaire due to the sensitive nature of the questions. It comprised of seven questions, which followed a nominal scale. Respondents were asked to choose a single response from a list.

\section{Measures}

Self-esteem was measured with five items, four of which were adopted from Judge, Erez, Bono, and Thoreson (2003) (Q1-Q4). One item (Q5) was created by the author. Example of items included "Overall I am satisfied with myself" and "Positive evaluations from others make me feel confident.” Generalized self-efficacy was measured with five times. All five were adopted from Judge et al. (Q6-Q10). Example of items included "If something looks too complicated, I will not even bother to try it" and "When I try, I generally succeed." Emotional stability was measured with five items. Four of the items were adopted from Judge et al. (Q11-Q13, and Q15). One item (Q14) was created by the author. Example of items included "Too often, when things go wrong, I get discouraged and feel like giving up" and "I worry a lot." Internal locus of control was measured with five items. All five items were adopted from Judge et al. (Q16-Q20). Example of items included "I determine what will happen in my life" and "When I get what I want, it's usually because I worked hard for it." Of the 20 items, nine were positively worded and 11 were negatively worded. Items that were positively worded were scored as follows: strongly disagree $=1$, disagree $=6$, uncertain $=0$, agree $=12$, and strongly agree $=18$. Those that were negatively worded had reverse scores: strongly disagree $=18$, disagree $=12$, uncertain $=0$, agree $=6$, strongly agree $=1$. Overall job satisfaction was measured with one item. Each of the 13 job facets were also measured with one item. Scores for all items were as follows: extremely dissatisfied $=1$, dissatisfied $=$ 6 , uncertain $=0$, satisfied $=12$, and extremely satisfied $=18$.

\section{Pilot Study}

A pilot study was conducted to evaluate the questionnaire to ensure that it was suitable for a diverse group of respondents. The pilot study was conducted at College of The Bahamas. The pilot test was distributed to six testers with different demographic characteristics (i.e. age, gender, occupation, and educational background) to allow diverse viewpoints. Five of the six testers were placed in a room, where each was instructed to critically appraise the instrument on the bases of structure and layout, wording and complexity, and question sequence. The sixth tester was recruited later and was also placed in a room, where he appraised the instrument. Completion times for all testers were also recorded. The profiles of testers are 
shown in table 2. Tester A completed the pilot in three minutes. She commented that the questionnaire's appearance was good, the wording was okay, and the structure and layout were very good. She did, however, have difficulty understanding what was meant by 'recognition' and 'responsibility' in the job satisfaction section (part 2, Q4 and Q5). She explained her difficulty understanding the questions was not related to wording or complexity, but rather she was unfamiliar with the concept as a whole as she worked for her family's business. Tester B completed the pilot in seven minutes. Initially she expressed her displeasure with the length of the questionnaire. However, she felt that the appearance, wording and layout were good and the structure was okay. Tester C encountered no complexity issues and had a completion time of two minutes. She commented that the appearance was okay, wording and structure were good, and layout was very good. Tester D also encountered no problems. His completion time was three minutes and commented that the appearance, wording, structure, and layout were all very good. Tester E completed the pilot in six minutes. He felt that the appearance, wording, structure, and layout of the questionnaire were all okay. He also expressed displeasure about the length. Finally, tester $\mathrm{F}$ completed the pilot in four minutes. He felt that the appearance, wording, structure, and layout of the questionnaire were good. The feedback of the pilot study suggested that the length of the questionnaire would be the primary issue amongst participants. Thus, five demographic questions were eliminated: Q3 - "What is the highest educational level you have attained?”; Q4 - "In which industry are you employed?”; Q5 - "What is your level of employment in the organization?”; Q6 - "How long have you worked in your current job?”; and Q7 - "What is your annual income?”. The questionnaire could not be shortened any further without jeopardizing vital measures. Thus, the final draft of the survey contained 36 items.

Table 2. Pilot Testers’ Profiles

\begin{tabular}{lllll}
\hline Tester & Age & Gender & Educational Background & Occupation \\
\hline A & $18-24$ & Female & High School Diploma & Gas Station Attendant \\
B & $55-64$ & Female & Master's Degree & Senior Private Secretary \\
C & $25-34$ & Female & Some College & Policewoman \\
D & $18-24$ & Female & High School Diploma & First-Line Manager \\
E & $18-24$ & Male & High School Diploma & Accountant \\
F & $25-34$ & Male & Some College & Radio Personality \\
\hline
\end{tabular}

\section{Procedure for Administering Instrument and Measurement Tools}

\section{Distribution Method}

A total of 15 fieldworkers assisted in distributing questionnaires. All fieldworkers were volunteers, who were students of College of The Bahamas (ranging from freshman to sophomore). They had no prior experience as interviewers, and thus in-house training was 
provided. Each was given a 30 minute training session, in which he or she was taught the manner in which to approach and communicate with the members of the public and participants. For example, each participant was instructed to make initial contact and to recruit volunteers using the following approach: "Good day, my name is and I am a student of College of The Bahamas. We are conducting a survey on job satisfaction and would appreciate if you would take part." The distribution method was mall-intercept. Prospective participants were approached by fieldworkers at various venues (shopping malls, grocery stores and plazas, shopping districts, college campuses, parks, and beaches) and asked to take part in the survey. Those that volunteered and met the criterion - employed were given a questionnaire and a pencil, and completed the questionnaire in the presence of fieldworkers. A cover letter was attached to each questionnaire. It explained the nature, purpose and objectives of the research. It professed that participation was voluntary and that respondents could withdraw at any time. Further, the cover letter addressed possible concerns with anonymity and confidentiality. An estimated completion time of 4 minutes was provided. A contact e-mail address was also provided to allow participants to request more information about the research and / or the results. At the end of the letter, I thanked participants in advance for their cooperation.

\section{Results}

To conduct the analysis personality scales were collapsed to two points (low and high). The highest possible score for each trait was 18 , so this value was divided by two to determine the mid-point (nine), which separated high and low trait scores. Personality scores for each of the four CSE traits were determined by calculating the average of the 5 questionnaire responses which measured each trait - for each respondent. The job satisfaction scale was also collapsed to two points (satisfied and dissatisfied). The highest possible score for overall job satisfaction and satisfaction with the 13 job facets was also 18 . This value was divided by two to determine the midpoint (nine), which separated satisfaction and dissatisfaction. Individuals that were neither satisfied nor dissatisfied with the item being measured were not included in the analysis. Consequently, the sample size varied at different stages of the analysis. The sample sizes in the analysis of the relationship between individual traits and each satisfaction item were as follows: overall job $n=261$; achievement $n=241$; advancement $n=272$; recognition $n=259$; responsibility $n=255$; work itself $n=255$, benefits $=300$; company policy and administration $n=238$; relationship with coworkers $n=268$; relationship with supervisor $n=295$; job security $n=307$; physical working conditions $n=249$; salary $n=321$; supervision $n=258$. In the regression analysis of individual traits, satisfaction scores for each item were used as is. In the analysis of all four traits, satisfaction scores were determined by calculating the average of all 14 satisfaction items. The sample size in this analysis was 384. The data was analyzed using Microsoft Office 2010 data analysis package. The data was summarized using cross tabulation. Regression analysis was used to derive relationships between personality traits and overall job satisfaction and satisfaction with job facets. The highest correlation derived for each trait in the regression analysis was further analyzed to determine if individuals with high average trait scores were more satisfied with the item that those with low average trait scores. This analysis was conducted using descriptive statistics 
and one-tailed two-sample t-tests.

\section{Job Satisfaction and Individual Personality Traits}

\section{The Relationship between Self-esteem and Job Satisfaction}

The results of the regression analysis relating self-esteem to satisfaction with overall job, and satisfaction with 13 job facets are provided in table 3 . As is shown, self-esteem was positively related to overall job satisfaction $(r=.04, \rho=n . s)$. The results of the F-test indicated, however, that the relationship was not significant $(F(1,259)=3.84, \rho=.50)$. Further, there was a negative relationship between self-esteem and 6 job facets (the work itself, benefits, company policy and administration, relationship with supervisor, job security, and physical working conditions). Self-esteem was positively related to seven job facets (achievement, advancement, recognition, responsibility, relationship with coworkers, salary, and supervision), but was only significantly related to achievement $(F(1,239)=3.84, p=n . s)$ and relationship with coworkers $(F(1,266)=3.84, p=n . s))$. The trait was most highly correlated with achievement $(r=.37, \rho=n . s)$, and $13.6 \%$ of the variance was explained by the linear relationship.

Table 3. Regression Analysis of the Relationship between Self-Esteem and Job Satisfaction

\begin{tabular}{lccccc}
\hline Variable & $R$ & $r^{2}$ & $F$ value & Significant $F$ & $D F$ \\
\hline OJ & 0.042 & 0.002 & 0.449 & 0.503 & 1,259 \\
ACH & $0.368^{*}$ & 0.136 & 37.523 & n.s & 1,239 \\
ADV & 0.054 & 0.003 & 0.798 & 0.373 & 1,270 \\
REC & 0.030 & 0.001 & 0.231 & 0.631 & 1,257 \\
RES & 0.092 & 0.009 & 2.179 & 0.141 & 1,253 \\
WI & -0.022 & 0.000 & 0.119 & 0.731 & 1,253 \\
BEN & -0.026 & 0.001 & 0.198 & 0.657 & 1,298 \\
CPA & -0.123 & 0.015 & 3.647 & 0.057 & 1,236 \\
RWC & $0.202 *$ & 0.041 & 11.277 & 0.001 & 1,266 \\
RWS & -0.131 & 0.017 & 5.153 & 0.024 & 1,293 \\
JSE & -0.007 & $n .5$ & 0.013 & 0.909 & 1,305 \\
PWC & -0.203 & 0.041 & 10.652 & 0.001 & 1,247 \\
SA & 0.067 & 0.004 & 1.423 & 0.234 & 1,319 \\
SUP & $\underline{0.033}$ & 0.001 & 0.285 & 0.594 & 1,257 \\
Mean Correlation & 0.027 & & & & \\
\hline
\end{tabular}

Note: $O J=$ overall job; $A C H=$ achievement; $A D V=$ advancement; $R E C=$ recognition; $R E S=$ responsibility; $W I=$ work itself; $B E N=$ benefits; $C P A=$ company policy and administration; $R$ WC $=$ relationship with coworkers; $R W S=$ relationship with supervisor; JSE = job security; PWC = physical working conditions; SA = salary; $S U P=$ supervision. 


\section{MlMacrothink}

Journal of Management Research

ISSN 1941-899X

2013, Vol. 5, No. 3

Cross tabulation of the data showed that $65 \%$ of respondents that were satisfied with achievement had high self-esteem. Whist about $72 \%$ of respondents that were dissatisfied with achievement had low self-esteem (see figure 2). Analysis of the data using descriptive statistics indicated a small difference in satisfaction with achievement between respondents with high self-esteem $(M=13.96, S D=2.83)$ and those with low self- esteem $(M=13.13$, $S D=2.37$ ). The t-test for satisfaction found that respondents with high self-esteem were more satisfied with achievement than those with low self-esteem $(t(112)=1.66, \rho=.04)$. The second t-test for dissatisfaction found that respondents with low self-esteem $(M=5.2, S D=$ 1.85) were not more dissatisfied with achievement than those with high self-esteem $(M=$ 4.62, $S D=2.27)(t(43)=1.68, \rho=.11)$.

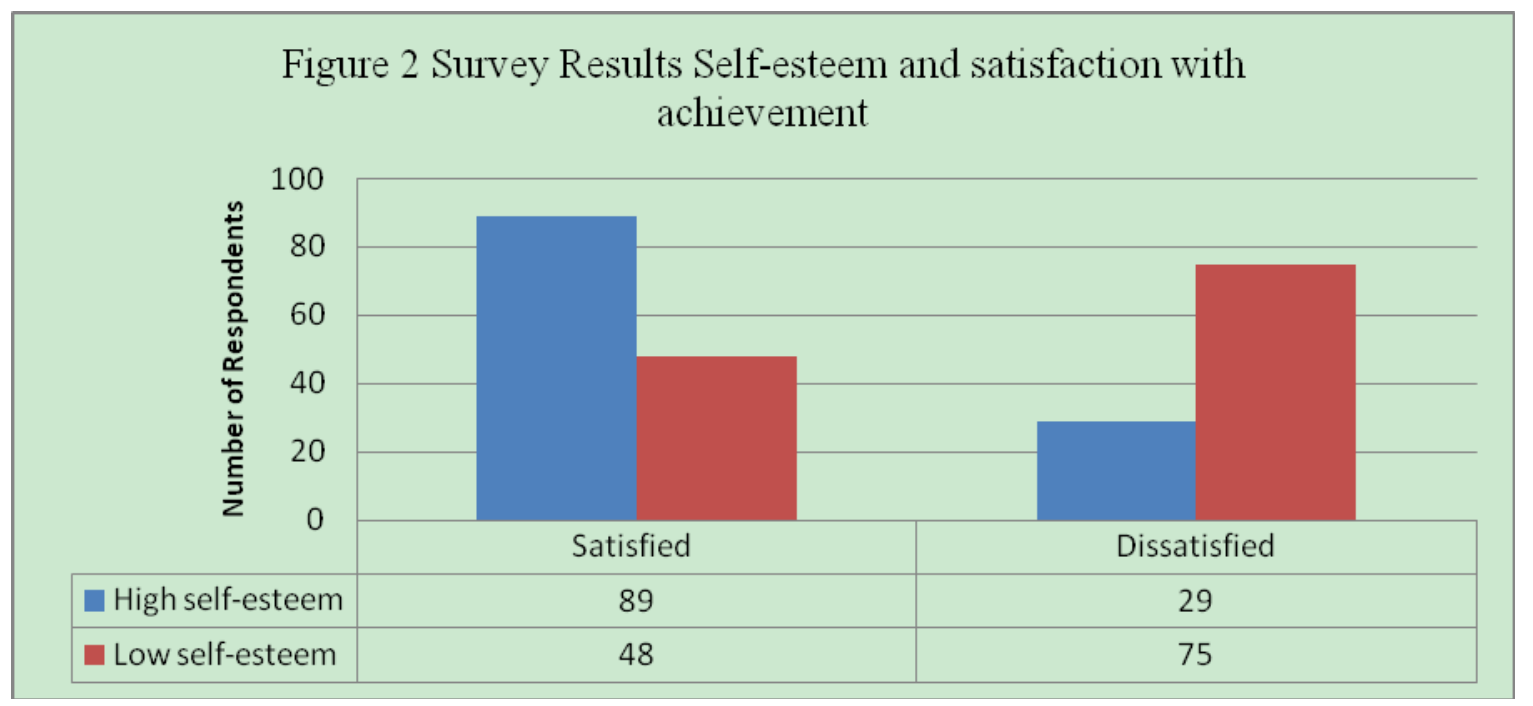

Figure 2. Survey Results Self-Esteem and Satisfaction with Achievement

\section{The Relationship between Generalized Self-Efficacy and Job Satisfaction}

Table 4 below provides the results of the regression analysis on the relationship between generalized self-efficacy and overall job satisfaction and satisfaction with 13 job facets. As is shown, generalized self-efficacy was positively correlated with overall job satisfaction ( $r$ $=.25, \rho=n . s)$. The regression indicated that this relationship was significant $\left(\mathrm{r}^{2}=.06\right.$, $F(1,259)=3.84 \rho=n . s)$. Further, this trait was positively correlated to 12 job facets. Positive correlations ranged from .12 for company policy and administration to .38 for recognition. F-tests indicated a significant relationships between generalized self-efficacy and all but one of the variables (company policy and administration $\left(\mathrm{r}^{2}=.01, F(1,236)=3.84, \rho=.07\right)$ ). As for the variables that were positively and significantly related to self-esteem, only a small proportion of the variances in satisfaction was explained by the linear relationships (explained variance ranged from .02 for relationship with supervisors to .15 for recognition). 
Table 4. Regression Analysis of the Relationship between Generalized Self-Efficacy and Job Satisfaction

\begin{tabular}{lccccc}
\hline & $R$ & $r^{2}$ & $F$-value & Significant $F$ & $D F$ \\
Variable & $0.254^{*}$ & 0.064 & 17.842 & n.s & 1,259 \\
OJ & $0.277^{*}$ & 0.077 & 19.892 & n.s & 1,239 \\
ACH & $0.248^{*}$ & 0.062 & 17.750 & n.s & 1,270 \\
REC & $0.381^{*}$ & 0.145 & 43.758 & n.s & 1,257 \\
RES & $0.308^{*}$ & 0.095 & 26.561 & n.s & 1,253 \\
WI & $0.184^{*}$ & 0.034 & 8.875 & 0.003 & 1,253 \\
BEN & $0.166^{*}$ & 0.028 & 8.451 & 0.004 & 1,298 \\
CPA & 0.117 & 0.014 & 3.250 & 0.073 & 1,236 \\
RWC & $0.343^{*}$ & 0.118 & 35.455 & $\mathrm{n} . \mathrm{s}$ & 1,266 \\
RWS & $0.143^{*}$ & 0.020 & 6.095 & 0.014 & 1,293 \\
JSE & $0.195^{*}$ & 0.038 & 12.031 & 0.001 & 1,305 \\
PWC & -0.045 & 0.002 & 0.504 & 0.478 & 1,247 \\
SA & $0.239^{*}$ & 0.057 & 19.336 & $\mathrm{n} . \mathrm{s}$ & 1,319 \\
SUP & $\underline{0.230^{*}}$ & 0.053 & 14.311 & 0.000 & 1,257 \\
Mean Correlation & 0.217 & & & & \\
\hline
\end{tabular}

Note: $O J=$ overall job; $A C H=$ achievement; $A D V=$ advancement $; R E C=$ recognition; $R E S=$ responsibility; $W I=$ work itself; $B E N=$ benefits; $C P A=$ company policy and administration; $R W C=$ relationship with coworkers; $R W S=$ relationship with supervisor; JSE $=$ job security; $P W C=$ physical working conditions; $S A=$ salary; $S U P=$ supervision.

Generalized self-efficacy was most strongly correlated with recognition. Cross tabulation of the data found that about $93 \%$ of respondents that were satisfied with recognition had high generalized self-efficacy. Whilst 34\% that were dissatisfied had low generalized self-efficacy (see figure 3). However, whilst respondents with high generalized self-efficacy were more likely to be satisfied with recognition, analysis of the data using descriptive statistics showed that respondents with low generalized self-efficacy were on average more satisfied with recognition $(M=14.25 S D=3.12)$ than those with high generalized self-efficacy $(M=13.47$, $S D=2.59$ ). In addition, respondents with high generalized self-efficacy $(M=5.10, S D=$ 1.93) were on average more dissatisfied with recognition than those with low generalized self-efficacy $(M=4.85, S D=2.15)$. The first t-test related to satisfaction found that respondents with low generalized self-efficacy were more satisfied with recognition than those with high generalized self-efficacy $(t(8)=1.86, \rho=.25)$. The second t-test for dissatisfaction found that respondents with high generalized self-efficacy were not more dissatisfied with recognition that those with low generalized self-efficacy $(t=(39)=1.68, \rho$ $=.30)$. 


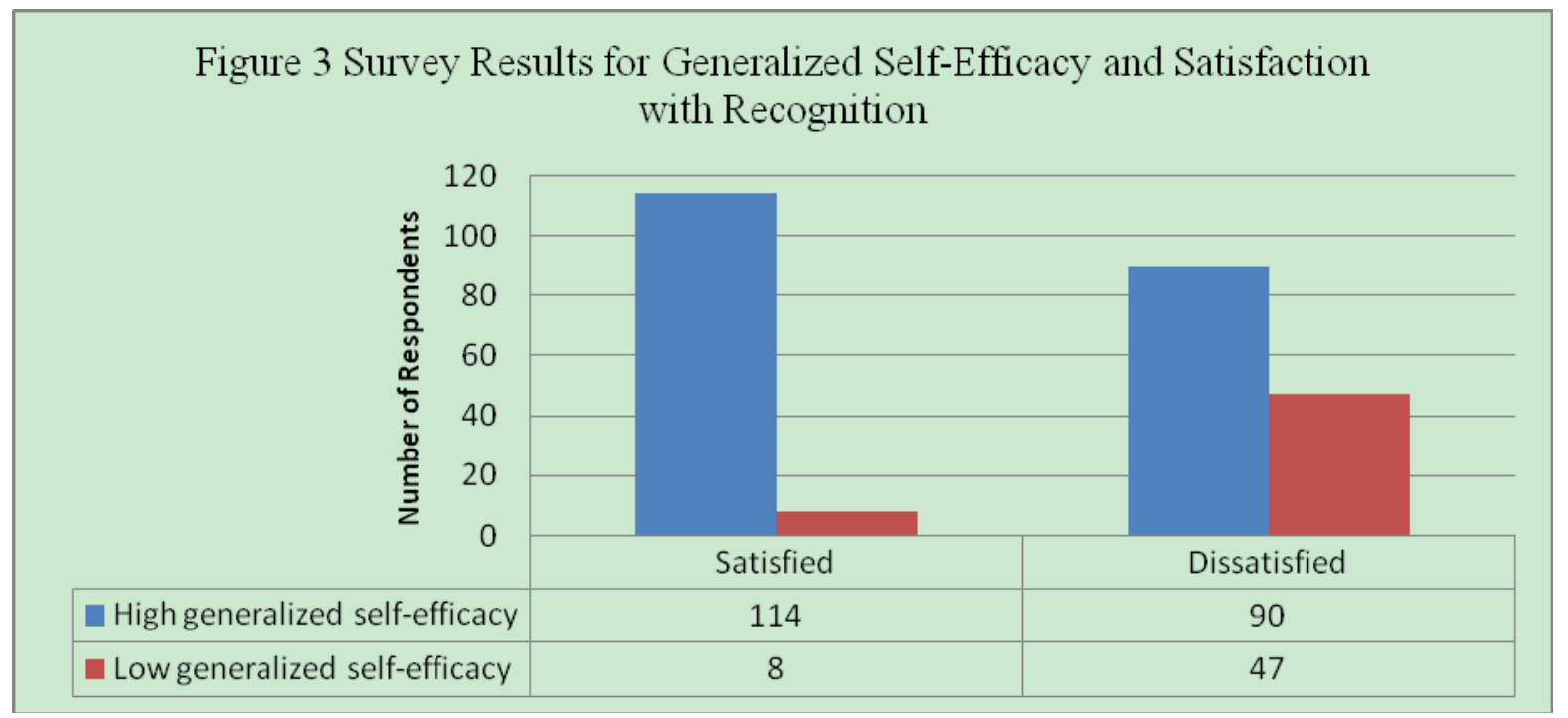

Figure 3. Survey Results for Generalized Self-Efficacy and Satisfaction with Recognition

\section{The Relationship between Emotional Stability and Job Satisfaction}

The results of the regression analysis relating emotional stability to overall job satisfaction and satisfaction with 13 job facets are provided in table 5 . As is shown, there was a positive relationship between emotional stability and overall job satisfaction $(r=.35, \rho=n . s)$. Results of the F-test supported that the relationship was significant $\left(r^{2}=.13, F(1,259)=3.84, \rho=\right.$ n.s). This trait was positively related to satisfaction with all 13 job facets. Further, results of the F-tests indicated a significant relationship between emotional stability and all but one job facet. A nonsignificant relationship existed between emotional stability and physical working conditions $\left(r^{2}=.02, F(1,247)=3.84, \rho=.06\right)$. As in the case of self-esteem and generalized self-efficacy, only a small proportion of the variance in satisfaction was explained by the linear relationships (explained variance ranged from .03 for company policy and administration and .18 for relationship with coworkers). 
Table 5. Regression Analysis of the Relationship between Emotional Stability and Job Satisfaction

\begin{tabular}{lccccc}
\hline Variable & $r$ & $r^{2}$ & $F$-value & Significant $F$ & $D F$ \\
\hline OJ & $0.354^{*}$ & 0.125 & 37.135 & $\mathrm{n} . \mathrm{s}$ & 1,259 \\
ACH & $0.368^{*}$ & 0.136 & 37.524 & $\mathrm{n} . \mathrm{s}$ & 1,239 \\
ADV & $0.307^{*}$ & 0.094 & 28.133 & $\mathrm{n} . \mathrm{s}$ & 1,270 \\
REC & $0.325^{*}$ & 0.106 & 30.420 & $\mathrm{n} . \mathrm{s}$ & 1,257 \\
RES & $0.366^{*}$ & 0.134 & 39.103 & $\mathrm{n} . \mathrm{s}$ & 1,253 \\
WI & $0.254^{*}$ & 0.064 & 17.439 & $\mathrm{n} . \mathrm{s}$ & 1,253 \\
BEN & $0.288^{*}$ & 0.083 & 27.000 & $\mathrm{n} . \mathrm{s}$ & 1,298 \\
CPA & $0.182^{*}$ & 0.033 & 8.067 & 0.005 & 1,236 \\
RWC & $0.423^{*}$ & 0.179 & 58.021 & $\mathrm{n} . \mathrm{s}$ & 1,266 \\
RWS & $0.205^{*}$ & 0.042 & 12.836 & 0.000 & 1,293 \\
JSE & $0.316^{*}$ & 0.100 & 33.750 & $\mathrm{n} . \mathrm{s}$ & 1,305 \\
PWC & 0.122 & 0.015 & 3.732 & 0.055 & 1,247 \\
SA & $0.356^{*}$ & 0.127 & 46.212 & $\mathrm{n} . \mathrm{s}$ & 1,319 \\
SUP & $\underline{0.273^{*}}$ & 0.075 & 20.614 & $\mathrm{n} . \mathrm{s}$ & 1,256 \\
Mean Correlation & 0.296 & & & & \\
\hline
\end{tabular}

Note. $O J=$ overall job; $A C H=$ achievement $; A D V=$ advancement $; R E C=$ recognition; $R E S=$ responsibility; $W I=$ work itself; $B E N=$ benefits; $C P A=$ company policy and administration; $R W C=$ relationship with coworkers; $R W S=$ relationship with supervisor; JSE = job security; $P W C=$ physical working conditions; SA = salary; SUP = supervision.

Emotional stability was most highly correlated with relationship with coworkers ( $r=.42, p=$ $n . s)$. Cross tabulation of the data found that about $55 \%$ of respondents that were satisfied with this job factor had high emotional stability, whilst about $74 \%$ that was dissatisfied had low emotional stability (see figure 4). Analysis of the data using descriptive statistics suggested that respondents with high emotional stability $(M=15.41, S D=2.99)$ were on average more satisfied with relationship with coworkers than those with low emotional stability $(M=14.68$, $S D=3.01)$, and that respondents with high emotional stability $(M=5.52, D S=1.50)$ were also on average more dissatisfied with relationship with coworkers than those with low emotional stability $(M=4.82, S D=2.13)$. The t-test for satisfaction supported that respondents with high emotional stability were not more satisfied with relationship with coworkers than those with low emotional stability $(t(139)=1.66, \rho=.10)$. The t-test for dissatisfaction found that respondents with high emotional stability were not more dissatisfied with relationship with coworkers than those with low emotional stability $(t(74)=$ 1.67, $\rho=.03)$. 


\section{Macrothink}

Journal of Management Research

ISSN 1941-899X 2013, Vol. 5, No. 3

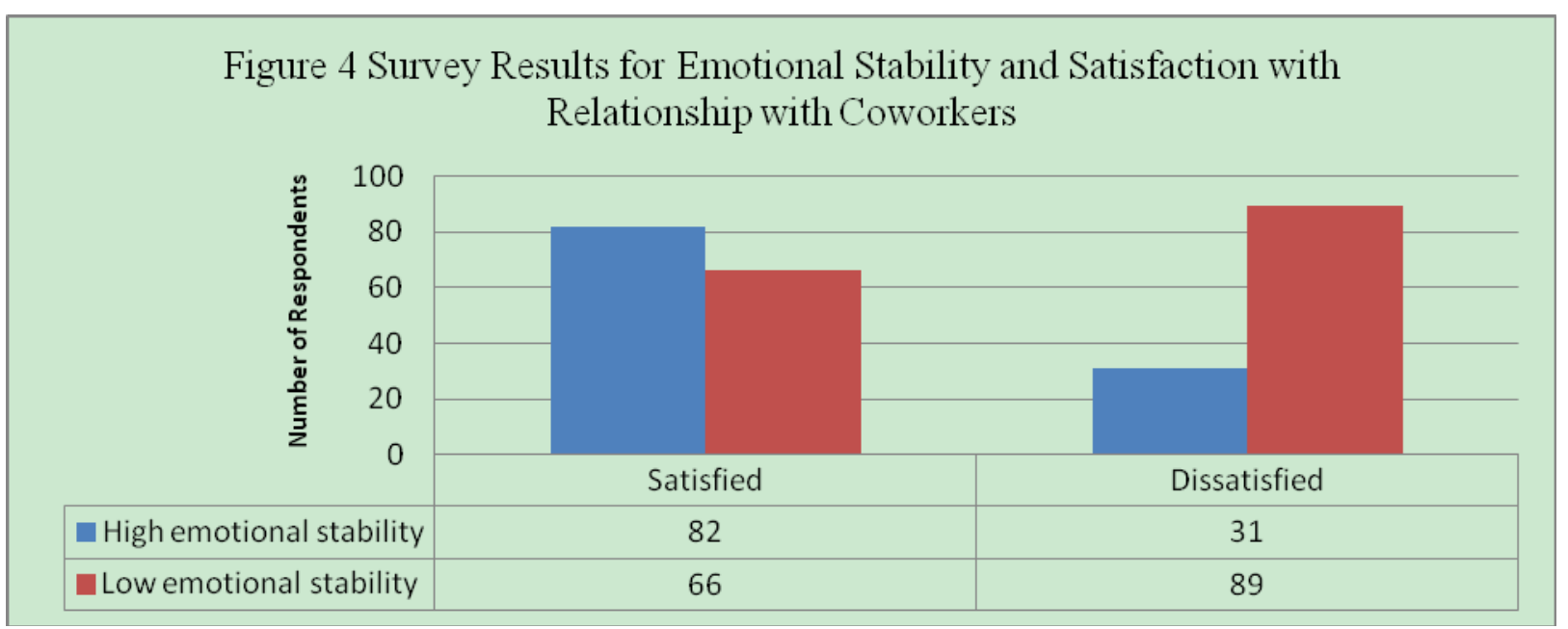

Figure 4. Survey Results for Emotional Stability and Satisfaction with Relationship with Coworkers

\section{The Relationship between Internal Locus of Control and Job Satisfaction}

Table 6 provides results of the regression analysis relating internal locus of control to overall job satisfaction and satisfaction with 13 job facets. As is shown, internal locus of control was positively related to overall job satisfaction $(r=.29, \rho=n . s)$. The F-test indicated that this relationship was significant $\left(r^{2}=.09, F(1,259)=3.84, \rho=n . s\right)$. The regression analysis also indicated that internal locus of control was positively related to all 13 job facets. The F-tests indicated that all of the relationships were significant. This trait explained a small proportion of the variance in the linear relationships (explained variance ranged from .05 for physical working conditions to .19 for recognition). 
Table 6. Regression Analysis of the Relationship between Internal Locus of Control and Job Satisfaction

\begin{tabular}{lccccc}
\hline Variable & $R$ & $R^{2}$ & $F$-value & Significant $F$ & $D F$ \\
\hline OJ & $0.291^{*}$ & 0.085 & 23.949 & n.s & 1,259 \\
ACH & $0.416^{*}$ & 0.173 & 50.159 & n.s & 1,239 \\
ADV & $0.314^{*}$ & 0.098 & 29.445 & n.s & 1,270 \\
REC & $0.435^{*}$ & 0.189 & 60.038 & n.s & 1,257 \\
RES & $0.366^{*}$ & 0.134 & 39.160 & n.s & 1,253 \\
WI & $0.309^{*}$ & 0.095 & 26.705 & n.s & 1,253 \\
BEN & $0.302^{*}$ & 0.091 & 29.812 & n.s & 1,298 \\
CPA & $0.311^{*}$ & 0.096 & 25.190 & n.s & 1,236 \\
RWC & $0.395^{*}$ & 0.156 & 49.110 & n.s & 1,266 \\
RWS & $0.377^{*}$ & 0.142 & 48.437 & n.s & 1,293 \\
JSE & $0.349^{*}$ & 0.122 & 42.200 & n.s & 1,305 \\
PWC & $0.232^{*}$ & 0.054 & 14.018 & 0.000 & 1,247 \\
SA & $0.347^{*}$ & 0.121 & 43.759 & n.s & 1,319 \\
SUP & $\underline{0.348^{*}}$ & 0.121 & 35.449 & n.s & 1,257 \\
Mean Correlation & 0.342 & & & & \\
\hline
\end{tabular}

Note: $O J=$ overall job; $A C H=$ achievement $; A D V=$ advancement; $R E C=$ recognition; $R E S=$ responsibility; $W I=$ work itself; $B E N=$ benefits; $C P A=$ company policy and administration; $R W C=$ relationship with coworkers; $R W S=$ relationship with supervisor; JSE $=$ job security; $P W C=$ physical working conditions; $S A=$ salary; $S U P=$ supervision.

Internal locus of control was most highly correlated with recognition $(r=.44, \rho=n . s)$. Cross tabulation of the data found that about $77.87 \%$ percent of respondents that were satisfied with recognition had high internal locus of control, whilst $81.75 \%$ that were dissatisfied had low internal locus of control (see figure 5). Analysis of the data using descriptive statistics suggested that individuals with high internal locus of control $(M=13.15, S D=2.37)$ were on average less satisfied with recognition than those with low internal locus of control $(M=15$, $S D=3.06)$, and that respondents with low internal locus of control $(M=4.52, S D=2.29)$ were on average more dissatisfied with recognition than those with high internal locus of control $(M=3, S D=2.50)$. The t-test for satisfaction indicated that individuals with low internal locus of control were more satisfied with recognition than those with high internal locus of control $(t(55)=1.67, \rho=n . s)$. The second t-test for dissatisfaction indicated that individuals with low internal locus of control were also more dissatisfied with recognition than those with high internal locus of control $(t(34)=1.69, \rho=.004)$. 


\section{Macrothink}

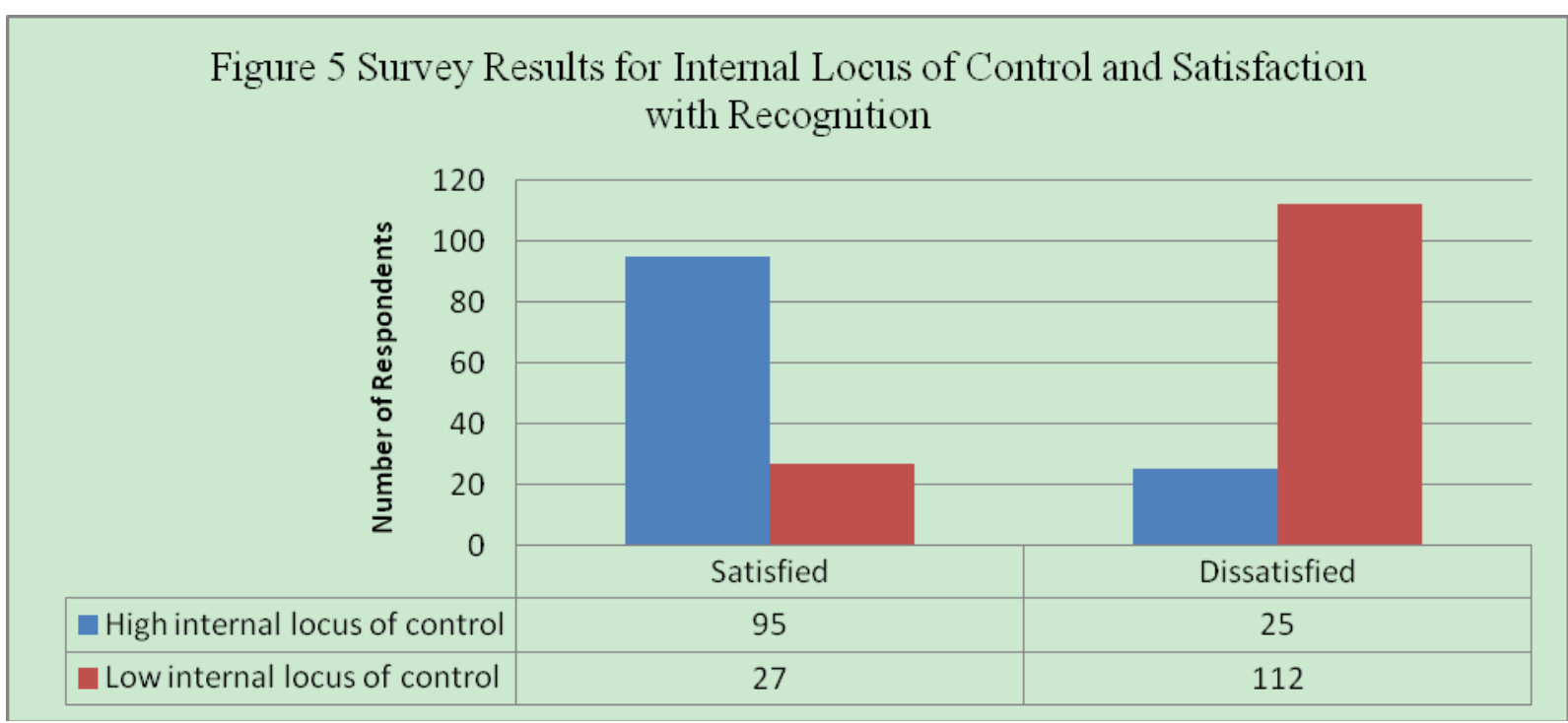

Figure 5. Survey Results for Internal Locus of Control and Satisfaction with Recognition

Of the four personality traits, internal locus of control had the highest mean correlation with job satisfaction $(r=.34)$. Following was emotional stability, generalized self-efficacy and self-esteem respectively (see table 7). All traits were positively related to job satisfaction.

Table 7. Mean Correlations between CSE Personality Traits and Job Satisfaction

\begin{tabular}{lll}
\hline Trait & K & Mean Correlation \\
\hline Self Esteem & 14 & 0.027 \\
Generalized Self-Efficacy & 14 & 0.217 \\
Emotional Stability & 14 & 0.296 \\
Internal Locus of Control & 14 & 0.342 \\
\hline
\end{tabular}

Note. $K=$ number of correlations

\section{Analysis of Group Traits and Job Satisfaction}

A multiple regression procedure was used to derive the best equation to predict job satisfaction. The analysis included all four traits and average job satisfaction score, which were determined by calculating the average satisfaction score for each respondent. The regression analysis indicated a moderate correlation between personality and job satisfaction $(r=.46, \rho=n . s)$. There was a positive relationship between job satisfaction and all but one trait (self-esteem $\left(\beta_{1}=-.43, \rho=n . s\right)$. All traits were significant in the model with the exception of generalized self-efficacy $\left(\beta_{2}=.04, \rho=.64\right)$. The overall model was significant 
$(F(4,379)=2.37, \rho=n . s)$, and $20.48 \%$ of the variance was explained by the regression.

\section{Discussion}

The purpose of the study was to describe the relationship between personality and job satisfaction. It was hypothesized that self-esteem was positively related to overall job satisfaction (hypothesis 1a) and satisfaction with 13 job facets (hypothesis 1b); generalized self-efficacy is positively related to overall job satisfaction (hypothesis 2a) and satisfaction with 13 job facets (hypothesis 2b); emotional stability was positively related to overall job satisfaction (hypothesis 3a) and satisfaction with 13 job facets (hypothesis $3 \mathrm{~b}$ ), and internal locus of control was positively related to overall job satisfaction (hypothesis 4a) and satisfaction with 13 job facets (hypothesis $4 \mathrm{~b}$ ). As hypothesized, self-esteem was positively related to overall job satisfaction (hypothesis 1a). Hypothesis $1 \mathrm{~b}$ was only partially supported by the data. Self-esteem was positively related to seven of the 13 job facets. The analysis supported that generalized self-efficacy was positively related to job satisfaction (hypothesis 2a). Hypothesis 2b, was partially supported by the data. Generalized self-efficacy was positively related to 11 of the 13 job facet. Hypothesis 3a, 3b, 4a, and 4b, were fully supported by the data. Both traits were positively related to overall job satisfaction and satisfaction with all 13 job facets.

The findings of this study are consistent with those of Judge and Bono (2001), where all four traits had a positive relationship with job satisfaction. However, unlike in their study where emotional stability was least correlated $(r=.24)$ and generalized self-efficacy was most correlated with overall job satisfaction $(r=.45)$, in the present study self-esteem was least correlated $(r=.04)$ and emotional stability was most correlated with overall job satisfaction $(r=.35)$. These differences are likely due to difference in analysis procedures. Bono and Judge's results were based on a meta-analysis which consisted of 169 correlations derived from over 1,000 studies, whereas the present study's results were based on one correlation. If results were reported based on the mean correlations, it would include 56 correlations. The reported results using this approach would be slightly different: self-esteem is least correlated with job satisfaction $(r=.027)$ and internal locus of control is most correlated with job satisfaction $(r=.34)$.

As regards individual traits, emotional stability was more strongly correlated with satisfaction with overall job, relationship with coworkers, and salary, than the other three traits. However, the explained variance, which ranged from .14 for overall job to .18 for relationship with coworkers, suggested that emotional stability was not a good predictor of overall job satisfaction or satisfaction with relationship with coworkers and salary. Internal locus of control was more strongly correlated with satisfaction with achievement, advancement, recognition, responsibility, work itself, benefits, company policy and administration, relationship with supervisors, job security, physical working conditions, and supervision, than the other three traits. Once again, the small proportion of explained variance (explained variance ranged from .05 for physical working conditions to .19 for recognition), suggested that internal locus of control would not be a strong predictor of satisfaction with the job facets. The results do support Judge (2001) assertion that individuals with high trait scores are more 
likely to be satisfied with their jobs. It is important to note, however, that such individuals are not necessarily more satisfied than those with low trait scores. The correlation between all four traits and job satisfaction was the highest observed in the study $(r=.46)$. The multiple regression also explained the greatest proportion of the variance in job satisfaction

$\left(R_{s d f}^{2}=.20\right)$. These results suggested that personality is a greater predictor of satisfaction

when traits are analyzed collectively rather than individually. Even so, a significant proportion of the variance was not explained by the multiple regression, thus indicating that all four traits combined were not substantial predictors of job satisfaction. Overall, all personality traits were positively related to job satisfaction. However, in accordance to the finding of Furnham et al. (2003), correlations were at best modest. The results suggested that personality was not a meaningful predictor of job satisfaction.

There were several notable limitations to this study. Firstly, the five point likert scale (used to measure personality traits) and five point numerical scale (used to measure job satisfaction) were not appropriate for the study. The neutral point on both scales led to the loss of a significant amount of data. A scale with no neutral point would have been more appropriate. Perhaps a four point scale, with strongly disagree, disagree, agree, and strongly agree in the case of personality assessment and extremely dissatisfied, dissatisfied, satisfied and extremely satisfied in the case of job satisfaction would have been better suited. Secondly, as all 384 observations could not be included in all aspects of the analysis, the results were not representative of the relationship between personality and job satisfaction amongst workers in The Bahamas. Thirdly, the results of the study may have been more significant if scales with high reliability and empirical validity were used. Finally, the study was based around self-reports and thus the degree of respondent bias is unknown. Future research on the relationship between personality and job satisfaction should focus not only on the likeliness of satisfaction due to positive affectivity associated with CSE traits, but also the difference in the magnitude of satisfaction between individuals with high and low traits scores. Further, research should focus on the collective influence of traits on job satisfaction, as the combined impact of traits appear to be more significant than the individual impact. Such a study, using a larger sample size, should find a more significant relationship between personality and job satisfaction.

\section{Conclusion}

The purpose of the study was to examine the relationship between personality and job satisfaction amongst workers in The Bahamas. The results indicated that there is a positive relationship between personality and job satisfaction. The findings are consistent with the literature (Judge and Bono, 2001; Judge, 2001) which found that all four core self-evaluation traits were positively related to satisfaction with overall job and that individuals with high trait scores are more likely to be satisfied with their jobs. However, whilst a greater number of respondents with high trait scores were satisfied with their jobs, they were not necessarily more satisfied than those with low trait scores. Additionally, just two traits (emotional stability and internal locus of control) were positively related to all 13 job facets. Mean 
correlations for individual traits showed that internal locus of control is most highly correlated with job satisfaction, followed by emotional stability, generalized self-efficacy, and self-esteem respectively. This relationship was even more significant for all four traits combined. However, traits, individually and collectively, explained a very small proportion of the variance in satisfaction, which suggested that personality is not a substantial predictor of job satisfaction. If this study was replicated with a larger sample size and more reliable personality scales, the relationship between personality and job satisfaction would be more significant.

\section{References}

Abraham, L. M., Arvey, R. D., Bouchard Jr., T. J., \& Segal, N. L. (1989). Job Satisfaction: Environmental or Genetic Components. Journal of Applied Psychology, 74(2), pp. 187-192. http://dx.doi.org/10.1037/0021-9010.74.2.187

Argyle, M. (1989). Do Happy Workers Work Harder? The effect of job satisfaction on work performance. Rotterdam: Universitaire Pers Rotterdam.

Bahama Journal. (2012, May 31). Hospital Maintenance Workers Protest. Retrieved September 4, 2012, from Bahamas News. Net: http://www.bahamasnews.net/story.php?rid=206202155

Bahamas Local. (2011, May 3). Social Workers Protest Minimum Wage. Retrieved September 4, 2012, from Bahamaslocal.com: http://www.bahamaslocal.com/newsitem/20935/Social_workers_protest_minimum_wage.htm 1

Bahamas Press. (2008, August 11). BTC WORKERS Blocks Bay Street Whilst ON STRIKE. Retrieved September 4, 2012, from Bahamas Press: http://www.bahamaspress.com/2008/08/11/btc-workers-blocks-bay-street-whilst-on-strike/

Behling, O., Labovitz, G., \& Kosmo, R. (1968). The Herzberg Controversy: A Critical Reappraisal. The Academy of Management Journal, 11(1), pp. 99-108. http://dx.doi.org/10.2307/255200

Bowen, B. E., \& Radhakrishna, R. B. (1991). Job Satisfaction of Argicultural Education Faculty: A Constant Phenomena. Journal of Agricultural Educatoin, 16-22. http://dx.doi.org/10.5032/jae.1991.02016

Brunborg, G. S. (2008). Core Self-Evaluations: A Predictor Variable for Job Stress. European Psychologist, 13(2), pp. 96-102. http://dx.doi.org/10.1027/1016-9040.13.2.96

Castillo, J. X., \& Cano, J. (2004). Factors Explaining Job Satisfaction Among Faculty. Journal of Agricultural Education, 45, 65-74. http://dx.doi.org/10.5032/jae.2004.03065

Charles G. Morris, A. A. (2008). Understanding Psychology, 8th edition. Upper Saddle River, New Jersey: Pearson Education, Inc.

Churchill, G. A., Ford, N. M., \& Walker, O. C. (1976, November). Organizational Climate 
and Job Satisfaction in the Salesforce. Journal of Marketing Research, 13(4), pp. 323-332. http://dx.doi.org/10.2307/3151014

Department of Statistics. (2011). The Labor Force and its Components: 2011. Nassau, New Providence: Bahamas Department of Statistics.

Erikson, E. H. (1978). Childhood and Society. New York: Norton.

Fleishman, J. A. (1984, June). Personality Characteristics and Coping Patterns. Journal of Health and Social Behavior 1984, 25(2), pp. 229-244. http://dx.doi.org/10.2307/2136671

Furnhama, A., Petridesa, K., Jackson, C. J., \& Cotter, T. (2002). Do personality factors predict job satisfaction? Personality and Individual Differences, 33, 1325-1342. http://dx.doi.org/10.1016/S0191-8869(02)00016-8

Ganzach, Y. (1998, October). Intelligence and Job Satisfaction. The Academy of Management Journal, 41(5), pp. 526-539. http://dx.doi.org/10.2307/256940

Hackman, R., \& Oldman, G. R. (1976). Motivation through the Design of Work: Test of a Theory. Organizational Behavior and Human Performance, 16, pp. 250-279. http://dx.doi.org/10.1016/0030-5073(76)90016-7

Hart, D., Atkins, R., Fegley, S., Robins, R. W., \& Tracy, J. L. (2003). Personality and Development in Childhood: A Person-Centered Approach. Monographs of the Society for $\begin{array}{llll}\text { Research in Child Development, } & 68(1), \quad \text { pp. }\end{array}$ http://dx.doi.org/10.1111/1540-5834.00232

Horwitz, A. V., Videon, T. M., Schmitz, M. F., \& Davis, D. (2003, June). Rethinking Twins and Environments: Possible Social Sources for Assumed Genetic Influences in Twin Research. Journal of Health and Social Behavio 44(2) , pp. 111-129. http://dx.doi.org/10.2307/1519802

Jonge, J. d., Bosma, H., Peter, R., \& Siegrist, J. (2000). Job Strain, effort-reward imbalance and employee well-being: a large-scale cross-sectional study. Social Science \& Medicine, 20, pp. 1317-1327. http://dx.doi.org/10.1016/S0277-9536(99)00388-3

Judge, T. A. (2009). Core Self-Evaluations and Work Success. Association for Psychological Science, 18(1), pp. 58-62.

Judge, T. A., \& Bono, J. E. (2001). Relationship of Core Self-Evaluations Traits-Self-Esteem, Generalized Self-Efficacy, Locus of Control, and Emotional Stability-With Job Satisfaction and Job Performance: A Meta-Analysis. Journal of Applied Psychology, 86(1), pp. 80-92. http://dx.doi.org/10.1037/0021-9010.86.1.80

Judge, T. A., \& Hulin, C. L. (1990). Job Satisfaction as a Reflection of Disposition: A Multiple Source Casual Analysis. Ithaca, NY: Cornell University.

Judge, T. A., \& Larsen, R. J. (2001, September). Dispositional Affect and Job Satisfaction: A Review and Theoretical Extension. Organizational Behavior and Human Decision Processes, 86(1), pp. 67-98. http://dx.doi.org/10.1006/obhd.2001.2973 
Judge, T. A., Erez, A., Bono, J. E., \& Thoresen, C. J. (2003). The Core Self-Evaluations Scale (CSES): Development of a measure. Personnel Psychology, 56, 303-331. http://dx.doi.org/10.1111/j.1744-6570.2003.tb00152.x

Judge, T. A., Heller, D., \& Mount, M. K. (2002). Five-Factor Model of Personality and Job Satisfaction: A Meta-Analysis. Journal of Applied Psychology, 87(3), pp. 530-541. http://dx.doi.org/10.1037/0021-9010.87.3.530

Judge, T., Locke, E., \& Durham, C. (1997). The Dispositional Causes of Job Satisfaction: A Core Evaluations Approach. Research in Organizational Behavior, 19, pp. 151-188.

Locke, E. A. (1969). What is Job Satisfaction? Organizational Behavior and Human Performance, 4(4), pp. 309-336. http://dx.doi.org/10.1016/0030-5073(69)90013-0

Locke, E. A., McClear, K., \& Knight, D. (1996). Self-Esteem and Work. International Review of Industrial/Organizational Psychology, 11, pp. 1-32.

Lykken, D. T., T. J. Bouchard, J., McGue, M., \& Tellegen, A. (1993). Heritability of Interests: A Twin Study. Journal of Applied Psychology, 78(4), pp. 649-661. http://dx.doi.org/10.1037/0021-9010.78.4.649

Markon, K. E., Krueger, R. F., Thomas J. Bouchard, J., \& Gottesman, I. I. (2002, October). Normal and Abnormal Personality Traits: Evidence for Genetic and Environmental Relationships in the Minnesota Study of Twins Reared Apart. Journal of Personality 70(5), pp. 662-694.

Maslow, A. H. (1943). Theory of Human Motivation. Psychological Review, 40, 370-396. http://dx.doi.org/10.1037/h0054346

Mathis, R. L., \& Jackson, J. H. (2008). Human Resource Management, 12th ed. Mason, OH: Cengage Learning.

Maume, D. J., \& Sebastian, R. (2007, January). Racial Compostion of Workgroups and Job Satisfaction Among Whites. Annals of the American Academy of Political and Social Science, 609, pp. 85-103. http://dx.doi.org/10.1177/0002716206295396

Missick, R. (2004, November 24). BEC Union Strike Threat For The Bahamas. Retrieved September 4, 2012, from BahamasB2B.com: http://www.bahamasb2b.com/news/wmview.php?ArtID=4417

Morris, C. G., \& Maisto, A. A. (2008). Understanding Psychology, 8th edition. Upper Saddle River, New Jersey: Pearson Education, Inc.

Ostroff, C. (1992). The Relationship Between Satisfaction, Attitudes, and Performance: An Organizational Level Analysis. Journal of Applied Science, 77(6), pp. 963-974.

Raosoft. (2004). Sample size calculator. Retrieved November 12, 2011, from Raosoft: http://www.raosoft.com/samplesize.html

Robbins, S. P., \& Judge, T. A. (2007, April 30). Organizational Behavior, 12th ed. Upper 
Saddle River, NJ: Pearson Education Inc.

Sanna, L. J. (2000, October). Mental Simulation, Affect, and Personality: A Conceptual Framework. Current Directions in Psychological Science, 9(5), pp. 168-173. http://dx.doi.org/10.1111/1467-8721.00086

Saunders, N. (2005, July 21). Inhumane conditions, Eight Mile Rock High teachers complain of classrooms being infested with bats and pigeons. Retrieved September 4, 2012, from The Freeport News: http://freeport.nassauguardian.net/national_local/282434968235717.php

Sen, K. (2008, July). Relationship between Job Satisfaction \& Job Stress Amongst Teachers \& Managers. Indian Journal of Industrial Relations, 44(1), pp. 14-23.

Staw, S. M., \& Ross, J. (1985). Stability in the Midst of Change: A Dispositional Approach to Job Attitude. Journal of Applied Psychology, 70, pp. 469-480. http://dx.doi.org/10.1037/0021-9010.70.3.469

Stello, C. M. (2011). Herzberg's Two-Factor Theory of Job Satisfaction: An Integrative Literature Review. Minnesota: Department of Organizational Leadership, Policy, and Development.

Tellegen, A., Bouchard Jr., T. J., Wilcox, K. J., Lykken, D. T., \& Rich, S. (1988). Personality Similarity in Twins Reared Apart and Together. Journal of Personality and Social Psychology, 54(6), pp. 1031-1039. http://dx.doi.org/10.1037/0022-3514.54.6.1031

Tischler, H. L. (2007). Understanding Psychology. Upper Saddle River, NJ: Prentice Hall.

Wahba, M. A., \& Bridwell, L. G. (1976). Maslow Reconsidered: A Review of Research on the Need Hierarchy Theory. Organizational Behavior and Human Performance, 15, pp. 212-240. http://dx.doi.org/10.1016/0030-5073(76)90038-6

Zikmund, W. Z. (2003). Business Research Methods. Mason, OH: South-Western. 